\title{
The moderating role of individual variables in the relationship between organizational justice and organizational commitment
}

\author{
Jale Minibas-Poussard \\ Institute of Management Research (IRG-EA2354), \\ Université Paris-Est, UPEC, UPEM, Créteil, France and \\ Department of Business Administration, Galatasaray University, Istanbul, Turkey \\ Jeanne Le Roy \\ Department of Management and Strategy, \\ European Business School of Paris, Paris, France, and \\ Turhan Erkmen \\ Department of Business Administration, \\ Yildz Technical University, Istanbul, Turkey
}

\begin{abstract}
Purpose - The purpose of this paper is to analyze the role of individual variables (organization-based self-esteem (OBSE) and work locus of control (WLOC)) that have been suspected to intervene as moderators on the relationship between organizational justice and organizational commitment.

Design/methodology/approach - Self-administered survey was completed by 272 bank employees in Istanbul, Turkey.

Findings - The results of moderation analyses clearly indicated a significant effect of OBSE and WLOC on the link between justice perceptions and organizational commitment. People are more committed to organizations when they have high OBSE. WLOC together with OBSE moderated the relationship between procedural justice and organizational commitment: people engaged less in their organizations when they perceived low procedural justice and reported lower OBSE. This relationship was revealed only when external WLOC scores were high.

Research limitations/implications - The study was conducted in Istanbul, Turkey and the sample was limited to 272 participants. These results show that managers should not only hire personnel with high OBSE but they also should provide a participative work atmosphere where employees can perform with all their potential and capacity that may help them reveal their internal WLOC. Theoretical and practical implications of the study are discussed in the end.

Originality/value - The study provides some valuable contributions to the existing body of literature by exhibiting the role of individual variables in the strong relationship between organizational justice and organizational commitment. The findings of the study also contribute to banking sector that has been critical and popular in Turkey since 2001.
\end{abstract}

Keywords Quantitative, Organizational justice, Organization-based self-esteem, Organizational commitment, Work locus of control

Paper type Research paper

\section{Introduction}

There has been intense interest within the HRM field regarding how HR practices can add value to organizations, leading to an increasing focus on high performance (Macky and Boxall, 2007). In addition, conceptual models have started to explore the link between $\mathrm{HR}$ practices and HR outcomes. HR practices can take three different forms: intended, actual and perceived (Wright and Nishii, 2006). Intended HR practices includes the policies and practices put together at organizational level such as criteria that are applied during decision making on rewards and retributions or the quality of relations within the

Received 7 December 2015 Revised 26 June 2016

11 December 2016

16 February 2017 Accepted 12 March 2017

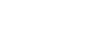
\section{(1)}


PR

46,8

1636

organizational hierarchy. These practices are then enacted by line management in the process of implementation, and may or may not be carried out as originally intended. The employee is ultimately the recipient of these practices forming his or her own perceptions of them. These perceptions then influence employee-level outcomes by affecting the way the employee thinks, feels or behaves (Purcell et al., 2008). A significant number of studies over the last decade showed that the respect of procedural and interactional justice in HR practices has the potential to improve the relationship between employees and organization with high level of organizational commitment. We present the argument that HR practices to ensure the effect of achieving high commitment depend on the extent to which employees perceive these practices to be fair, both in terms of the process and the quality of interaction. Indeed, the respect to organizational justice in HR practices therefore emerges as a key element in understanding the performance of employees in their organization. However, some studies reported that there are some arguments about the precise effect of HR practices on higher organizational commitment as the link in between the variables may also be affected by other factors (Marchington and Wilkinson, 2005). These limits also emerged from Colquitt et al. (2013) meta-analysis. They suggested that a substantial amount of variation exists in the relationship between organizational justice and organizational commitment. The authors argued that this variation could be caused by moderating effects of individual variables since it is not clear that the relative importance and contribution of various types of justice are stable among employees. While justice judgments are mainly evaluated based on organizational events and social organizational entities (Cropanzano et al., 2001), individual variables (self-variables and personality variables) also tend to bias the way people evaluate and react to justice in their environment (Brockner et al., 1998).

In summary, the present study contributes to organizational justice practices by clarifying the role of individual variables in determining organizational commitment. More precisely, it empirically examines the moderating role of organizational-based self-esteem (OBSE) and work locus of control (WLOC) in the relationship between procedural and interactional justice and organizational commitment.

Among all organizations, banks are considered to be one of the most stressful ones in the world (Ebiringa, 2011). This is also the case with the banking sector in Turkey. The crisis that was experienced in 2001 had a great impact on Turkey. Particularly, the banks that were incumbents till that crisis were either transferred or sold to the Organization of Saving Deposit and Insurance Funds. While the number of banks that operated in Turkey was 79 by 2000, it was decreased to 50 by 2003 (The 2009s Report of Banking Regulation and Supervision Agency) despite the following developments, and particularly the rise of foreign banks in the sector. The Banks Association of Turkey Report of 2015-2016 stated that the number of branches and employment declined in recent years. As a consequence of acquisitions and mergers, banks recruited many experienced and qualified employees from other competing banks with better salaries and opportunities. Accordingly, holding experienced and qualified employees with commitment to the banks they work for has become a critical issue. Due to the current dynamic structure in this sector in Turkey, we have decided to conduct our study in the banking sector.

\section{Theoretical background and hypotheses}

\section{Organizational settings: the relationship between organizational justice and commitment}

The term organizational justice refers to perceived fairness of workplace outcomes or processes (Folger and Cropanzano, 2001), and it encompasses in particular, procedural justice - referring to the evaluation of the criteria that are applied during decision making on rewards and retributions (Thibaut and Walker, 1975), and interactional justice - explaining the perceived quality of relations within the organizational hierarchy 
(Bies and Moag, 1986; Greenberg and Cropanzano, 1993). Scholars have repeatedly shown the connection between different forms of justice and organizational commitment from both theoretical and empirical standpoints. One of the useful concepts in the study of the relationships of identification and involvement between organizations and their employees is organizational commitment (Porter et al., 1974). Meyer and Allen (1991) have defined organizational commitment as a psychological state characterizing the relationship of an employee with the organization and with implications for the decision to stay as a member of the organization or not (p. 67). Allen and Meyer (1996) also stated that organizational commitment represents psychological link between the employee and the organization and making the employee less likely to leave the organization voluntarily (p. 252). Organizational commitment emerges today as a central variable in understanding organizational behavior. Early research findings underlined the impact of employees' organizational commitment on their performance and attendance (e.g. Dessler, 1999; Yousaf et al., 2015). Over the past 20 years, researchers have examined predictors of organizational commitment, revealing links among a variety of organizational dimensions such as organizational support, psychological contract, organizational climate, organizational values or workplace attachment (Kalliath et al. 1999; Meyer et al., 2002; Le et al., 2012). A number of studies have confirmed positive links between organizational commitment and organizational justice (Cohen-Charash and Spector, 2001; Cohen and Veled-Hecht, 2010; Colquitt et al., 2013; Ohana, 2014) more specifically with procedural justice (Mossholder et al., 1998; Masterson et al., 2000; Gopinath and Becker, 2000). Similar links have also been verified for interactional justice and organizational commitment (Chang, 2002; Aryee et al., 2002; Simons and Roberson, 2003). This relationship was confirmed by many studies in Turkey (Cihangiroğlu, 2011; Iş1k et al., 2012; Bağc1, 2013; Ay and Koç, 2014):

H1. Procedural and interactional justices are positively related to organizational commitment.

Nevertheless, a review of these research findings reveals that the strength of this relationship varies considerably from one study to another. For example, the relationship between procedural justice and affective commitment reported by Folger and Konovsky (1989) is rather a moderate correlation $(r=29)$, while Meyer and Smith (2000) reported a stronger link $(r=75)$ in between them. However, research on organizational commitment as well as on perceived justice suggests that the understanding of the exact nature of this relationship deserves further study. These limits are underlined by Vandenberghe (2009), in a book reviewing the current state of knowledge on organizational commitment. They argue that the simple effect of antecedents, such as organizational, on organizational commitment, does not allow a fine understanding of the context favorable to its development. In particular, they encourage researchers to examine the interaction between individual factors and work experiences as a mechanism for organizational commitment. In this way, interesting question in this regard is whether the interaction of explanatory factors such as individual variables interfere the relationship between justice and commitment. As related literature pointed out before, both commitment and justice perceptions have individual aspects as well as organizational aspects. Thus, the assumption about the role of individual variables between justice and commitment is the main concern of this study. In this sense, Judge and his colleagues (e.g. Judge et al., 1998; Judge and Bono, 2001; Bono and Judge, 2003) proposed a concept called core self-evaluation. Core self-evaluation refers to individuals' fundamental assessment about themselves and their self-worth. Incorporated into their concept of core self-evaluations are four dispositional traits: self- esteem, generalized self-efficacy, locus of control (LOC) and low neuroticism. According to Judge et al. (1997), these specific traits indicate a single, higher-order factor that forms the basis for other, more specific evaluations.
Moderating role of individual variables

1637 
PR

46,8

1638

In the present study, it was intended to test the specific role of two components of core self-evaluation (self-esteem and LOC) as moderator variables in the relationship between justice perception and organizational commitment.

\section{Self-esteem in organizational settings}

Self-esteem as a personality variable has been widely searched, most probably caused by the belief that it can influence how we as individuals think, feel and accordingly behave (Brockner, 1988). As described by Korman (1970) earlier, self-esteem is an overall evaluation of our self-worth and the extent to which an individual sees himself or herself as a "competent need satisfying individual" (p. 32). Thus, OBSE refers to an employee's evaluation of his or her self-perceived value, personal adequacy, competency and worthiness as an organizational member in an organizational context (Pierce Gardner et al., 1989). Self-esteem plays an important role in predicting employee attitudes and behaviors (e.g. Brockner et al., 1998; Judge and Bono, 2001). A number of studies report a positive relationship between experiences of organizational fairness and OBSE (for a review see Pierce and Gardner, 2004). According to De Cremer and Sedikides (2005), both procedural justice and interactional justice communicate respect and acceptance toward people through their self-perceptions. Moreover, a study conducted in a Korean bank observed that high OBSE had an impact on organizational commitment (Lee and Peccei, 2007); compared to individuals with low self-esteem, individuals with high self-esteem (having a positive view of themselves) appear to be keener to have a high level of organizational commitment. This assumption has recently been supported by the findings of a more recent meta-analysis on the predictors and consequences of OBSE (Bowling et al., 2010) findings of a analysis positive relationship between OBSE and job satisfaction, organizational commitment, job involvement, in-role-performance and citizenship work behavior as well as positive job attitudes in the workplace in general. Thus, the role played by OBSE as a moderator in the relationship between perception of organizational context and organizational outcomes has been identified in many western and non-western culture studies (e.g. Hui and Lee, 2000; Wiesenfeld et al., 2007; Hameed et al., 2013; Çakmak-Otluoğlu, 2015) in such a way that individuals with high OBSE were more sensitive to organizational justice. However, the moderator role of self-esteem in the relationship between organizational justice and organizational commitment is not yet tested. Based on this gap, we aimed to test OBSE as a moderator variable in the relationship between justice perceptions and specific outcomes:

H2. The relationship between organizational justice perceptions (interactional and procedural) and organizational commitment is moderated by OBSE. People with high OBSE are more likely to display evidence of a positive relationship between organizational justice and organizational commitment than people with low OBSE.

\section{LOC in organizational settings}

Several authors have discussed organizational commitment from a cognitive angle, suggesting that the tendency of a person to internalize and be identified with the goals, norms and values of the organization would be seen as a predictor of organizational commitment (Meyer and Herscovitch, 2001; Meyer et al., 2006; Kell and Motowildo, 2012). This tendency to internalize or externalize the causes of a situation can be measured in terms of LOC. WLOC defines the degree of control felt in the professional environment (Spector, 1988). The WLOC is considered as a relatively stable personality trait across situations (Luthans et al., 1987). Rotter (1966) based on his observations concluded that people generally sensitive to rewards tend to attribute the cause or the control of events to their own efforts and are said to have an internal work locus of control (IWLOC). 
In contrast, individuals insensitive to rewards and reinforcements, so to organizational justice, tend to attribute the cause and control of what happens to them to factors outside themselves, such as luck or fate, and have an external work locus of control. Thus, IWLOC is positively related to positive work experience such as job satisfaction, job motivation, organizational commitment and negatively related to negative work experience such as turnover intention, job stress and overall burnout (for reviews see, $\mathrm{Ng}$ et al., 2006; Bowling et al., 2010). More specifically, a number of studies have found significant correlations between IWLOC and organizational commitment (e.g. Luthans et al., 1987; Coleman et al., 1999; Meyer et al., 2002; Ng et al., 2006; Popoola, 2009; Munir and Sajid, 2010; Suman and Srivastava, 2012). All of these studies reported that individuals with an internal LOC are more likely to be committed to the organization than those with an external LOC. Luthans et al. (1987) provided three potential explanations for the relationship between LOC and organizational commitment. First, those with an internal WLOC are likely to report higher levels of commitment because they perceive that they have control over their work environment. In order to maintain cognitive consistency, internals are likely to be committed to organizations that allow them to control their environment. Second, since internals are likely to perceive more alternatives than those with an external WLOC and because freedom of choice is related to commitment, internals will feel more committed to the organization that they decide to participate. Third, because internals are more likely to take action when dissatisfied with a situation (particularly by leaving the organization), only committed internals are expected to remain with an organization. Apart from being an independent variable which has effects on several outcome variables, WLOC has also been examined as a moderator variable. Moreover, according to the self-interest model theory (Thibaut and Walker, 1975), individuals are concerned about procedural justice because they want more control over the distribution of resources. This model also leads us to the hypothesis that individuals with IWLOC, who have a stronger belief in what they are receiving is due to their actions and the ones who expect reinforcements are more likely to think that procedural and interactional justices are not random and will be maintained. It is in this context that the organizational commitment model and the selfinterest model support the plausibility of a moderating effect of the WLOC in the relationship between justice and organizational commitment. Considering the findings of all these studies, we generated hypotheses to test WLOC as a moderator variable in the relationship between justice perception and specific outcomes:

H3. The relationship between organizational justice evaluations (interactional and procedural) and organizational commitment is moderated by WLOC. It is assumed that only when externality is low, individuals are expected to link their perceptions of organizational justice with their organizational commitment.

\section{The purpose of the study}

Considering the above mentioned proceedings and expanding directions of the previous research and literature, we would like to test the relationship between justice perceptions and organizational commitment with the moderating effects of individual variables such as WLOC and OBSE in the relationship between the two variables. Since the moderating effects of individual variables between justice perceptions and organizational outcomes such as organizational commitment have not widely been examined in previous studies, this study may present a different approach and model for future studies in terms of the link between the variables involved. In summary, our exploration would extant literature to identify the moderating role of OBSE and WLOC on the relationship between organizational justice perceptions and organizational commitment. In order to further explore these relationships, a research model is presented in Figure 1 . Since this study took place in
Moderating role of individual variables

1639 
PR

46,8

1640

Turkey, the results may draw attention to one of the most promising developing cultures in a non-western cultural environment:

H4. The relationship between organizational justice perceptions (interactional and procedural) and organizational commitment is moderated by the relationship between OBSE and WLOC. In other words, we aimed to find that only when OBSE is high and when externality is low, individuals are expected to link their perceptions of organizational justice with their organizational commitment.

\section{Methodology \\ Sample}

The study was conducted in three private banks in Istanbul, Turkey. The three banks were chosen based on their similarity in how they are structured and how they operate. Ten branches were selected from each bank based on official permission that was collected. Participants who volunteered to contribute to this study by responding to the questionnaire were assured of the confidentiality of their responses. Questionnaires were delivered in the morning and collected back at the end of the very same day. Each questionnaire was placed in an envelope so that confidentiality would be assured. Of 600 questionnaires delivered, 272 of them were returned $(N=272)$. The majority of the respondents were 35 years old, 57 percent of them were female and 60 percent were married. In total, 55 percent of the sample group had more than five years of experience in banking, 80 percent were university graduates. In total, 36 percent held their current position for over five years, while 15 percent for less than a year. In total, 39 percent were expert staff while 36 percent were middle-line managers and 25 percent employees.

\section{Measurement}

The instruments of the study were translated to Turkish and then back translated to its original language (English) by two bilingual academics as was suggested by Brislin's (1986) instructions. Scales of this study were initially used in an academic study that Turkey was also included (see Bastounis et al., 2005). Consequently, they showed satisfactory psychometric properties (Cronbach's $\alpha$ s are above 0.70).

The questionnaire of the study contrary five sections: the demographic characteristics of the respondents, the scales of procedural and interactional justice, OBSE, WLOC and organizational commitment:

(1) Procedural justice: the scale constructed by Naumann and Bennett (2000) (adapted from Moorman, 1991) was employed to measure the procedural justice ranging from 1 to 5. Example items: "Decisions taken by our superiors respect coherent rules and procedures," "Our superiors ask our opinion before making decisions" (Cronbach's $\alpha=0.70)$.

(2) Interactional justice: three items scale (based on Colquitt, 2001) evaluating the quality of relationships with hierarchical superiors was applied. Example items: "Generally our superiors treat us with respect," "Generally our superiors treat us with dignity" (Cronbach's $\alpha=0.72$ ).

Figure 1.

Hypothesized moderation effect of OBSE and WLOC

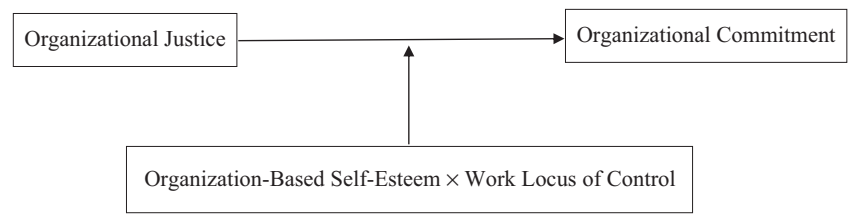


(3) OBSE: ten items scale ranging from 1 to 5 (Pierce et al., 1989) was implemented. Example items: "In my work place, I am trusted," "In my work place, I am important" (Cronbach's $\alpha=0.90$ ).

(4) WLOC: 16 -items scale ranging from 1 to 6 , where higher scores indicate externality (Spector, 1988) was delivered. Example items "Most employees have more influence on their supervisors than they think they do," "Most people are capable of doing their jobs well if they make the effort" (Cronbach's $\alpha=0.70$ ).

(5) Organizational commitment: three items inspired from Mowday et al. (1979) measuring organizational commitment, on a scale ranging from 1 to 5 were employed. Example items: "If it is necessary for my organization, I would accept to work in my office longer than usual," "I would recommend my organization to a person searching for employment without hesitation” (Cronbach's $\alpha=0.75$ ).

\section{Results}

The results of the study will be presented in two sections: correlation analyses between the variables and interaction analyses between dependent and independent variables considering the effect of moderating variables in between.

\section{Correlation analyses}

The results of the correlation analyses are shown in Table I. As predicted in H1, the two components of organizational justice which are procedural and interactional justice were positively correlated with organizational commitment $(r=0.43$ and $r=0.44$, respectively, $p \leqslant 0.01)$. Another finding of the study is that OBSE was positively correlated with justice perceptions (for procedural justice $r=0.40$ and for interactional justice $r=0.31, p \leqslant 0.01$ ) whereas the same kind of relationship was revealed between justice perceptions and WLOC (for procedural justice $r=-0.40$ and for interactional justice $r=-0.48, p \leqslant 0.01$ ). These results supported our assumptions. In addition, according to previous research, OBSE and WLOC were related to organizational commitment $(r=0.44$ and $r=-0.38$, respectively, $p \leqslant 0.01)$.

\section{Moderating effects}

According to the method described by Aiken and West (1991), the three variables were first centered and the interaction term was calculated based on the centered scores. To test our hypothesis, we conducted a series of interaction analyses on SPSS following the Preacher and Hayes (2008) method using their process on SPSS. The moderating effect of the two self-variables on the relationship between justice perceptions and organizational commitment was examined in order to test H2-H4. The findings are presented in consistence with Fitzsimons's (2008) recommendations.

\begin{tabular}{lcccccr}
\hline & $M$ & SD & 1 & 2 & 3 & 4 \\
\hline 1. Work LOC & 51.84 & 10.49 & & & & \\
2. O-B Self-Esteem & 37.45 & 5.87 & $-0.29 * *$ & & & \\
3. Procedural justice & 27.89 & 7.23 & $-0.40^{* *}$ & $0.40^{* * *}$ & & \\
4. Interactional justice & 10.35 & 2.50 & $-0.48^{* *}$ & $0.31^{* *}$ & $0.66^{* *}$ & \\
5. Organizational commitment & 11.07 & 2.50 & $-0.38^{* *}$ & $0.44^{* *}$ & $0.43^{* *}$ & $0.44^{* *}$ \\
Notes: Higher WLOC scores & $=$ externality. ** $p \leqslant 0.01$ & & & &
\end{tabular}

Moderating role of individual variables 
PR

46,8

1642

Figure 2.

Moderating effect of OBSE on the relationship between perceived procedural justice and organizational commitment

Figure 3.

Moderating effect of OBSE on the relationship between perceived interactional justice and organizational commitment
The moderating effect of OBSE on the relationship between justice perceptions and organizational commitment (H2) was significant for both dimensions of perceived organizational justice. The results of organizational commitment were perceived in three independent variables: OBSE, procedural justice (strong perception of justice vs low perception of justice), and the term "interaction." The results show a significant interaction effect between self-esteem and perceived procedural justice $\left(R=0.56, R^{2}=0.30, F=41.33\right.$, $\beta=0.21, p \leqslant 001$; see Figure 2). To explore this interaction, we initially examined the slope of OBSE at every level of perception of procedural justice. The slope is positive and significant when the perceived level of justice is high $(\beta=0.27, t=7.18, p \leqslant 0.001)$ and the slope is not significant when the level of justice is low $(\beta=-0.11, t=1.10, p=0.27)$. We also conducted a floodlight analysis using the Johnson- Neyman (1936) technique to identify the level of OBSE where there is a significant difference in terms of the level of procedural justice. Individuals with a level of OBSE above $15.68\left(\beta_{J N}=0.06\right.$, standard error $\left.=0.026, p \leqslant 0.05\right)$ have a high level of organizational commitment when procedural justice is high.

In addition to this, the results show a significant interaction effect between self-esteem and perceived interactional justice $\left(R=0.56, R^{2}=0.31, F=41.54, \beta=0.15, p \leqslant 001\right.$; see Figure 3). To explore this interaction, we initially examined the slope of OBSE at
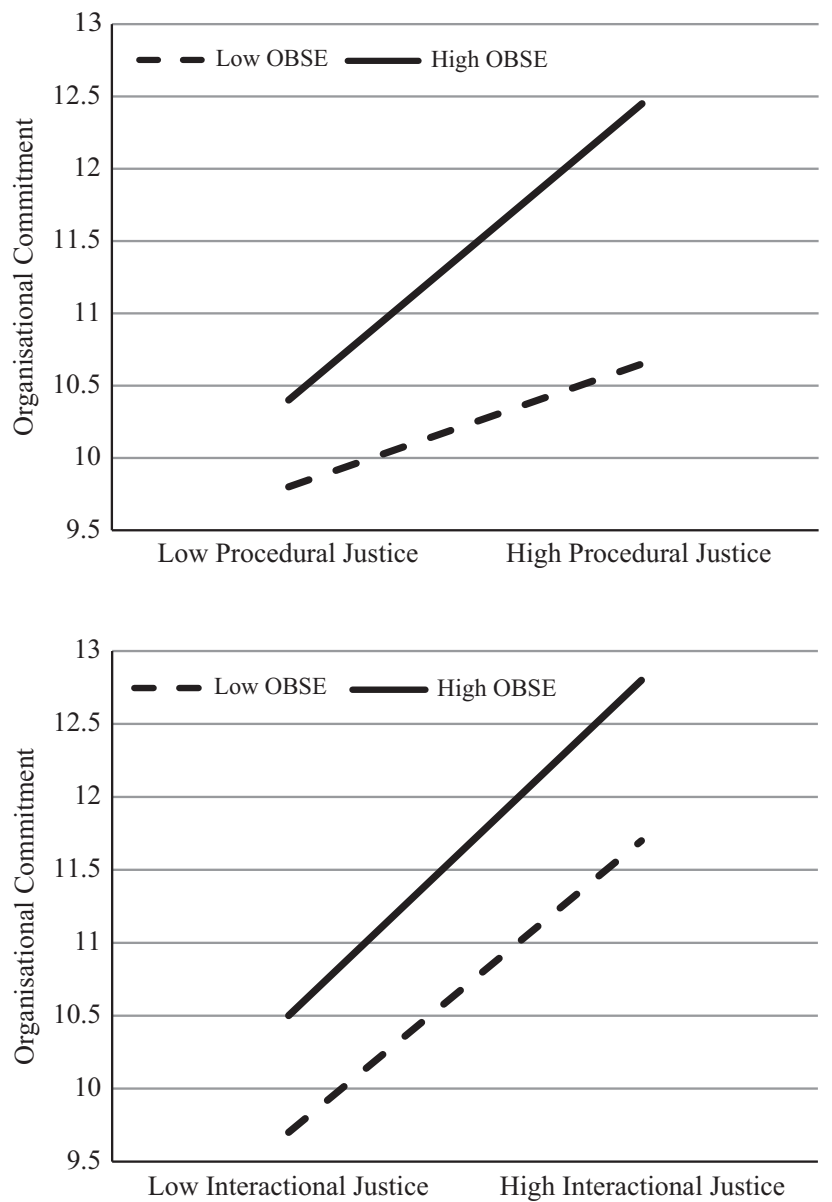
every level of perception of interactional justice. The slope is positive and significant when the perceived level of justice is high $(\beta=0.47, t=5.77 p \leqslant 0.001)$ and the slope is not significant when the level of justice is low $(\beta=0.19, t=1.82, p=0.07)$. In addition, we conducted a floodlight analysis using the Johnson-Neyman technique to identify the level of OBSE for where there is a significant difference in terms of the level of interactional justice. Individuals with a level of OBSE above $14.55\left(\beta_{J N}=0.04\right.$, e.s $=0.10$, $p \leqslant 0.05)$ have a high level of organizational commitment when interactional justice is high, too.

In other words, people engaged more in organizational commitment when they perceived high organizational justice (procedural or interactional) and this relationship was justified only when OBSE was high. There was no significant relationship between organizational commitment and organizational justice when OBSE was low.

The moderating effect of WLOC on the relationship between justice perceptions (both dimensions) and organizational commitment (H3) was non-significant. However, when the two individual variables were tested together on the relationship between procedural justice perceptions and organizational commitment, a significant effect $\left(R=0.18, R^{2}=0.03\right.$, $F=9.39, \beta=-0.18, p \leqslant 01$; see Figure 4) was determined. To explore the three way interaction, we initially examined the slopes of WLOC at every level of the interaction between perception of procedural justice and OBSE. The slope is negative and significant when the perceived level of justice and OBSE are low and WLOC is high $(\beta=-0.23, t=5.78$ $p \leqslant 0.001)$. The slope is not significant when the level of justice and OBSE are low and WLOC is low $(\beta=-0.04, t=1.12 p=0.26)$. A floodlight analysis was conducted using the Johnson-Neyman technique to identify the level of WLOC where there is a significant difference in terms of the level of the interaction between procedural justice and OBSE. Individuals with a level of WLOC above $33\left(\beta_{J N}=0.03\right.$ e.s $\left.=0.007, p \leqslant 0.05\right)$ have a weaker organizational commitment when procedural justice and OBSE are low. In other words, when external WLOC is high and OBSE is low, people are less committed to their organization in the case of low procedural justice. The same moderation effect was not found to be valid for the relationship between interactional justice and organizational commitment.

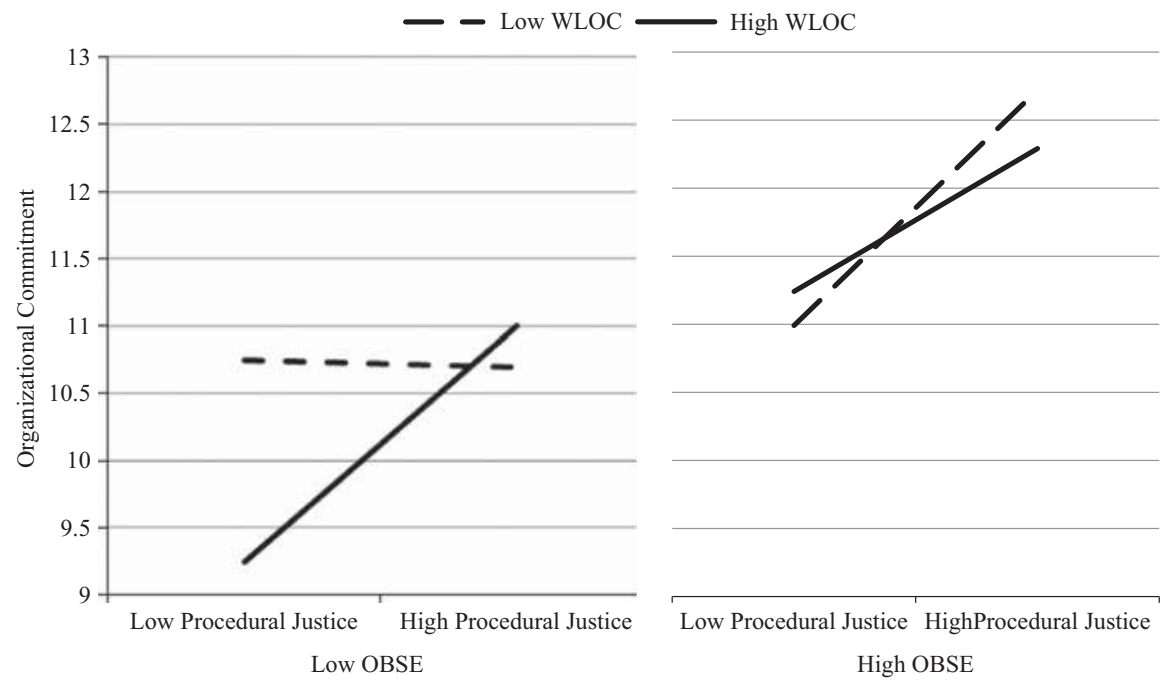

Moderating role of individual variables

1643

Note: High work LOC = external orientation

Figure 4 .

Moderating effect of OBSE and WLOC on the relationship between perceived procedural justice and organizational commitment 
PR

46,8

1644

\section{Discussion}

The positive relationship that was found between organizational justice and organizational commitment in our study is an important finding as also was suggested by the related literature (Colquitt et al., 2012; Aryee et al., 2013; Bing et al., 2014). Most of the organizational justice studies conducted in Turkey (Cihangiroğlu, 2011; Iş1k et al., 2012; Bağc1, 2013; Ay and Koç, 2014) confirmed the effect of organizational justice on organizational commitment.

Our study contributes to the literature on the relationship between HR practices with respect to fairness on procedure and on interpersonal treatment and organizational commitment. The results bring an answer to the limits on the relationship between organizational justice and organizational commitment underlined by Vandenberghe (2009). Thus, the main findings to emerge from the study are twofold.

First, we found a positive relationship between procedural/interactional justice and organizational commitment among people with high self-esteem but not among people with low OBSE. OBSE, as the perception of one's being significant, capable and worthy, explains that people who perceive justice in their organizational environment also have strong feelings of organizational commitment. Our findings corroborate also earlier research findings on the significant role of OBSE to influence one's positive attitude and behavior at the workplace (Pan et al., 2014) such as job satisfaction, job involvement, in-role job performance as well as organizational commitment and organizational citizenship behavior (Bowling et al., 2010; Pierce et al., 1989). These results can be understood better by considering the fact that employees with high OBSE are certain about the belief that they are trusted, valued and contributing organization members (Gardner and Pierce, 1998; Pierce et al., 1993). So workers with high OBSE could maintain their self-perceptions by developing positive job attitudes whereas workers with low OBSE developed negative job attitudes.

Second, according to the results of our study, WLOC, alone itself did not have the same effect that OBSE had on the relationship between organizational justice and organizational commitment. Instead, WLOC along with OBSE had a moderating effect on the relationship between procedural justice and commitment. When procedural justice is low with high external WLOC and low OBSE, employees are less committed to their organization. These results can be explained by the fact that OBSE and WLOC do not play the same role on work-related attitude and behavior. OBSE seems to be more autonomous while WLOC have to interact with other self-evaluations (Judge et al., 1997). So, OBSE yielded stronger relationship with both satisfaction and performance than did WLOC (Chen et al., 2004). Interaction between OBSE and WLOC can be understood better by considering the fact that individuals with high OBSE tend to have higher positive affectivity, higher need for achievement and internal locus of control (Pierce and Gardner, 2004). Judge et al. (1997) tested the role of core self-evaluations by integrating it with such traits as self-esteem, LOC, self-efficacy and emotional stability. Later, Judge (2009) argued how important the place of LOC in the context of core self-evaluations. He reported that the importance of LOC lies beneath the interaction between LOC and self-esteem. These findings highlight the critical role of people's self-conceptions in shaping their reactions to the evaluative information inherent in procedural treatment.

\section{Limitations and future research}

In total, 600 respondents were intended but 272 of them responded back to the questionnaire. Only three private banks in Istanbul with ten branches of each bank were involved in the study. Because of the time pressure and financial restrictions, the number of banks and branches was limited. Another reason for this limitation was the difficulty to get permission from the banks to collect data. The public banks were not involved in this study. Public and private banks can be compared in future studies to see if the effect of justice 
perceptions on commitment makes any difference from one to another with or without the moderating role of individual variables. The study was limited by the use of survey and scales only while it could have also been supported by qualitative methods, particularly case studies to comprehend the exact meaning of individual variables between justice and commitment relationship from managerial aspect.

Furthermore, the concept of "focus of attention at work" in Gardner and Pierce's (2013) study could also be included in future research models together with the role of OBSE and WLOC on organizational commitment and organizational justice relationship. New research models can also be designed including other variables such as psychological capital (Luthans et al., 2007) in order to discuss if OBSE and WLOC can be considered as human resource strengths and psychological capacities as explained by Luthans (2002) in his positive organizational behavior approach. Therefore, HR practitioners can take into account these strengths and capacities for performance improvement in the workplace.

\section{Managerial and HR implications}

Our exploration of the "black box" debate on the link between HR practice and individual performance has implications for HR practices. First, the findings of the present study highlight how important commitment to justice rules can be through the implementation of $\mathrm{HR}$ procedures in organizations. When the implementation of HR procedures seriously consider the rules of consistency, bias suppression, accuracy, paying attention to correct ability, representativeness and ethicality, the organizational commitment perceived by colleagues is high (e.g. Leventhal, 1980).

Second, our findings draw attention to the importance of such individual variables as OBSE and WLOC from the way organizations see and evaluate their employees. Considering the results of our study, we can suggest that HR should not only hire personnel with high OBSE but they also should provide a participative work environment where they can perform with all their potential and capacity that may help them reveal their internal WLOC. Work-related experiences (e.g. opportunities to engage in self-direction and self-control, opportunities to place our job on the focus of our life) have a tremendous impact on OBSE (Pierce and Gardner, 2004; Gardner and Pierce, 2013). In managerial skills development trainings, HR can reinforce managers' personal skills by explaining how OBSE and WLOC can be used in coaching and mentoring processes in teams. Indeed, team-related experiences (e.g. opportunities to reinforce their importance for the effectiveness of the team) can increase members' self-esteem (Norman et al., 2015). From a different point of view, it can be assumed that positive individual traits can be associated with positive work environment as were also suggested by Judge and Ilies (2004), Seligman et al. (2005), and Wright and Cropanzano (2004). Based on their studies, positive work environment combined with positive individual traits can foster positive feelings experienced at work which may finally lead to employees' happiness and well-being.

\section{References}

Aiken, L.S. and West, S.G. (1991), Multiple Regression: Testing and Interpreting Interactions, Sage, Newbury Park, CA.

Allen, N.J. and Meyer, J.P. (1996), "Affective, continuance and normative commitment to the organization: an examination of construct validity", Journal of Organizational Behavior, Vol. 49 No. 3, pp. 252-276.

Aryee, S., Budhwar, P. and Chen, Z. (2002), "Trust as a mediator of the relationship between organizational justice and work outcomes: test of a social exchange model", Journal of Organizational Behavior, Vol. 23 No. 3, pp. 267-285.
Moderating role of individual variables

1645 
PR

46,8

1646

Aryee, S., Walumbwa, F., Mondejar, R. and Chu, C.W.L. (2013), "Accounting for the influence of overall justice on job performance: integrating self-determination and social exchange theories", Journal of Management Studies, Vol. 5 No. 2, pp. 231-252.

Ay, G. and Koç, H. (2014), "Örgütsel adalet algısı ile örgütsel bağlllık düzeyi arasındaki ilişkinin belirlenmesi: Ögretmenler üzerinde bir inceleme”, Journal of Business Research Turk, Vol. 6 No. 2, pp. 67-90.

Bağcı, Z. (2013), "Çalışanların örgütsel adalet algılarının örgütsel bağlllıkları üzerindeki etkisi: Tekstil sektöründe bir inceleme”, Uluslararası Yönetim İktisat ve İşletme Dergisi, Vol. 9 No. 19, pp. 163-184.

Bastounis, M., Finkelstein, R. and Minibas-Poussard, J. (2005), "Sentiments de justice, estime de soi, auto efficacité perçue et sentiment de contrôle au travail : approche transculturelle", IAE de Paris-GREGOR, No. 2, pp. 7-22.

Bies, R.J. and Moag, J.F. (1986), "Interactional justice: communication criteria of fairness", in Lewicki, R.J., Sheppard, B.H. and Bazerman, M.H. (Eds), Research on Negotiations in Organizations, Vol. 1, JAI Press, Greenwich, CT, pp. 43-55.

Bing, M., Shanshi, L. and Donglai, L. (2014), "The impact of organizational identification on the relationship between procedural justice and employee work outcomes", Social Behavior and Personality, Vol. 42 No. 3, pp. 437-444.

Bono, J.E. and Judge, T.A. (2003), "Core self-evaluations: a review of the trait and its role in job satisfaction and performance”, European Journal of Personality, Vol. 17, pp. 5-18.

Bowling, N.A., Eschleman, K.J., Wang, Q., Kirkendall, C. and Alarcon, G.A. (2010), "Meta-analysis of the predictors and consequences of organization-based self-esteem", Journal of Occupational and Organizational Psychology, Vol. 83 No. 3, pp. 601-626.

Brislin, R.W. (1986), "The wording and translation of research instruments", in Lonner, W.L. and Berry, J.W. (Eds), Field Methods in Cross-Cultural Research, Sage, Newbury Park, CA, pp. 159-162.

Brockner, J. (1988), Self-Esteem at Work: Research, Theory and Practice, Lexington Books, Lexington, MA.

Brockner, J., Heuer, L., Siegel, P.A., Wiesenfeld, B., Martin, C., Grover, S., Reed, T. and Bjorgvinsson, S. (1998), "The moderating effect of self-esteem in reaction to voice: converging evidence from five studies", Journal of Personality and Social Psychology, Vol. 75, pp. 394-407.

Çakmak-Otluoğlu, K.Ö. (2015), "Örgütsel nedenlerle yaşanan olumsuz şokların iş performansına etkisi: Örgüt temelli özsaygının biçimlendirici değişken rolü”, ODTÜ Gelişme Dergisi, Vol. 42 No. 2, pp. 221-246.

Chang, E. (2002), "Distributive justice and organizational commitment revisited: Moderation by layoff in the case of Korean employees", Human Resources Management, Vol. 41 No. 2, pp. 261-270.

Chen, G., Gully, S.M. and Eden, D. (2004), "General self-efficacy and self-esteem: toward theoretical and empirical distinction between correlated self-evaluations", Journal of Organizational Behavior, Vol. 25 No. 3, pp. 375-395.

Cihangiroğlu, N. (2011), "Askeri doktorların örgütsel adalet algıları ile örgütsel bağlllıkları arasındaki ilişkinin analizi”, Gülhane Tip Dergisi, Vol. 53 No. 1, pp. 9-16.

Cohen, A. and Veled-Hecht, A. (2010), "The relationship between organizational socialization and commitment in the workplace among employees in long-term nursing care facilities", Personnel Review, Vol. 39 No. 5, pp. 537-556.

Cohen-Charash, Y. and Spector, P.E. (2001), "The role of justice in organizations: a meta-analysis", Organizational Behavior and Human Decision Processes, Vol. 25 No. 3, pp. 278-321.

Coleman, D.F., Irving, G.P. and Cooper., C. (1999), "Another look at the locus of control - organizational commitment relationship: it depends on the form of commitment", Journal of Organizational Behavior, Vol. 20 No. 6, pp. 995-1001. 
Colquitt, J. (2001), "On the dimensionality of organizational justice: a construct validation of a measure", Journal of Applied Psychology, Vol. 86 No. 3, pp. 386-400.

Colquitt, J.A., LePine, J.A., Piccolo, R.F., Zapata, C.P. and Rich, B.L. (2012), "Explaining the justice-performance relationship: trust as exchange deepener or trust as uncertainty reducer?”, Journal of Applied Psychology, Vol. 97 No. 1, pp. 1-15.

Colquitt, J.A., Rodell, J.B., Long, D.M., Zapata, C.P., Conlon, D.E. and Wesson, M.J. (2013), “Justice at the millennium, a decade later: a meta-analytic test of social exchange and affect-based perspectives", Journal of Applied Psychology, Vol. 98 No. 2, pp. 199-236.

Cropanzano, R., Rupp, D.E., Mohler, C.J. and Schminke, M. (2001), "Three roads to organizational justice”, in Ferris, J. (Ed.), Research in Personnel and Human Resources Management, JAI Press, Greenwich, CT, pp. 1-113.

De Cremer, D. and Sedikides, C. (2005), "Self-uncertainty and responsiveness to procedural justice", Journal of Experimental Social Psychology, Vol. 41 No. 2, pp. 157-173.

Dessler, G. (1999), "How to earn your employees commitment”, Academy of Management Executive, Vol. 13 No. 2, pp. 58-67.

Ebiringa, O.T. (2011), "Benchmarking incidence of distress in the Nigerian banking industry on Altman scale”, Serbian Journal of Management, Vol. 6 No. 2, pp. 221-230.

Fitzsimons, G.J. (2008), "Death to dichotomizing”, Journal of Consumer Research, Vol. 35 No. 1, pp. 5-8.

Folger, R. and Cropanzano, R. (2001), "Fairness theory: justice as accountability", in Greenberg, G. and Cropanzano, R. (Eds), Advances in Organizational Justice, Stanford University Press, Stanford, CA, pp. 1-55.

Folger, R. and Konovsky, M.A. (1989), "Effects of procedural and distributive justice on reactions to pay raise decisions", Academy of Management Journal, Vol. 32 No. 1, pp. 115-130.

Gardner, D.G. and Pierce, J.L. (1998), "Self-esteem and self-efficacy within the organizational context", Group and Organization Management, Vol. 23 No. 1, pp. 48-70.

Gardner, D.G. and Pierce, J.L. (2013), "Focus of attention at work and organization-based self-esteem", Journal of Managerial Psychology, Vol. 28 No. 2, pp. 110-132.

Gardner, D.G. and Pierce, J.L. (2015), “Organization-based self-esteem in work groups”, Group Processes and Intergroup Relations, Vol. 19 No. 3, pp. 1-15.

Gopinath, C. and Becker, T.E. (2000), "Communication, procedural justice and employee attitudes: relationship under condition of divestiture”, Journal of Management, Vol. 21, pp. 63-83.

Greenberg, J. and Cropanzano, R. (1993), "The social side of fairness: interpersonal and informational classes of organizational justice”, Justice in the Workplace: Approaching Fairness in Human Resource Management, Lawrence Erlbaum Associates, Hillsdale, NJ.

Hameed, Z., Maqbool, A. and Athar, M.R. (2013), "How to increase employee performance: investigating the impact of incentive motivators and organization-based self-esteem in a Pakistani perspective”, Middle-East Journal of Scientific Research, Vol. 14 No. 5, pp. 696-702.

Hui, C. and Lee, C. (2000), "Moderating effects of organization-based self-esteem on organizational uncertainty: employee response relationships”, Journal of Management, Vol. 26 No. 2, pp. 215-232.

Işık, O., Uğurluoğlu, Ö. and Akbolat, M. (2012), "Sağlık kuruluşlarında örgütsel adalet algılarının örgütsel bağlılı̆̆a etkisi”, Doğus Üniversitesi Dergisi, Vol. 13 No. 2, pp. 254-265.

Johnson, P.O. and Neyman, J. (1936), “Tests of certain hypotheses ad their application to some educational problems”, Statistical Research Memoires, Vol. 1, pp. 59-77.

Judge, T. and Ilies, R. (2004), "Is positiveness in organizations always desirable?", Academy of Management Executive, Vol. 18 No. 4, pp. 151-155.

Judge, T.A. (2009), "Core self-evaluations and work success", Current Directions in Psychological Science, Vol. 18 No. 1, pp. 58-62.
Moderating role of individual variables

1647 
PR

46,8

1648

Judge, T.A. and Bono, J.E. (2001), "Relationship of core self-evaluation traits - self-esteem, generalized self-efficacy, locus of control, and emotional stability - with job satisfaction and job performance", Journal of Applied Psychology, Vol. 86 No. 1, pp. 80-92.

Judge, T.A., Locke, E.A. and Durham, C.C. (1997), "The dispositional causes of job satisfaction: a core evaluations approach", Research in Organizational Behavior, Vol. 19, pp. 151-188.

Judge, T.A., Locke, E.A., Durham, C.C. and Kluger, A.N. (1998), "Dispositional effects on job and life satisfaction: the role of core evaluations", Journal of Applied Psychology, Vol. 83 No. 1, pp. 17-34.

Kalliath, T.J., Bluedorn, A.C. and Strube, M.J. (1999), "A test of value congruence effects", Journal of Organizational Behavior, Vol. 20 No. 7, pp. 1175-1198.

Kell, H.J. and Motowildo, S.J. (2012), "Deconstructing organizational commitment: associations among its affective and cognitive components, personality antecedents, and behavioral outcomes", Journal of Applied Social Psychology, Vol. 42 No. 1, pp. 213-251.

Korman, A.K. (1970), "Toward an hypothesis of work behavior", Journal of Applied Psychology, Vol. 54 No. 1, pp. 31-41.

Le Roy, J. and Rioux, L. (2012), "The mediating role of workplace attachment in the relationship between organizational commitment and organizational citizenship behavior", International Review of Social Psychology, Vol. 25 Nos 3-4, pp. 211-233.

Lee, J. and Peccei, R. (2007), "Perceived organizational support and affective commitment: the mediating role of organization-based self-esteem in the context of job insecurity", Journal of Organizational Behavior, Vol. 28 No. 6, pp. 661-685.

Leventhal, G.S. (1980), "What should be done with equity theory?", Social Exchange, Springer, pp. 27-55.

Luthans, F. (2002), "Positive organizational behavior: developing and managing psychological strengths", Academy of Management Executive, Vol. 16 No. 1, pp. 57-72.

Luthans, F., Baack, D. and Taylor, L. (1987), "Organizational commitment: analysis of antecedents", Human Relations, Vol. 40 No. 4, pp. 219-236.

Luthans, F., Avolio, B.J., Avey, J.B. and Norman, S.M. (2007), "Positive psychological capital: measurement and relationship with performance and satisfaction", Personal Psychology, Vol. 60 No. 3, pp. 541-572.

Macky, K. and Boxall, P. (2007), "The relationship between 'high-performance work practices' and employee attitudes: an investigation of additive and interaction effects", The International Journal of Human Resource Management, Vol. 18 No. 4, pp. 537-567.

Marchington, M. and Wilkinson, A. (2005), "Direct participation and involvement”, Managing Human Resources: Personnel Management in Transition, CIPD, London, pp. 398-423.

Masterson, S.S., Lewis, K., Goldman, B.M. and Taylor, M.S. (2000), "Integrating justice and social exchange: the differing effects of fair procedures and treatment on work relationships", Academy of Management Journal, Vol. 43 No. 4, pp. 738-748.

Meyer, J., Becker, T. and Van Dick, R. (2006), "Social identities and commitments at work: toward an integrative model”, Journal of Organizational Behavior, Vol. 27 No. 4, pp. 665-683.

Meyer, J.P. and Allen, N.J. (1991), "A three component conceptualization of organizational commitment", Human Resource Management Review, Vol. 1 No. 1, pp. 61-89.

Meyer, J.P. and Herscovitch, L. (2001), "Commitment in the workplace: toward a general model", Human Resource Management Review, Vol. 11 No. 3, pp. 299-326.

Meyer, J.P. and Smith, C.A. (2000), "HRM practices and organizational commitment: test of a mediation model", Canadian Journal of Administrative Sciences, Vol. 17 No. 4, pp. 319-331.

Meyer, J.P., Stanley, D.P., Herscovitch, L. and Topolnytsky, L. (2002), "Affective, continuance and normative commitment to the organization: a meta-analysis of antecedents, correlates and consequences", Journal of Vocational Behavior, Vol. 61 No. 1, pp. 20-52.

Moorman, R.H. (1991), "Relationship between organizational justice and organizational citizenship behavior: do fairness perceptions influence employee citizenship?", Journal of Applied Psychology, Vol. 76 No. 6, pp. 845-855. 
Mossholder, K.W., Bennett, N. and Martin, C.L. (1998), "A multilevel analysis of procedural justice context”, Journal of Organizational Behavior, Vol. 19 No. 2, pp. 131-141.

Mowday, R., Steers, R. and Porter, L. (1979), “The measurement of organizational commitment”, Journal of Vocational Behavior, Vol. 14, pp. 224-227.

Munir, S. and Sajid, M. (2010), "Examining locus of control (LOC) as a determinant of organizational commitment among university professors Pakistan”, Journal of Business Studies Quarterly, Vol. 1 No. 3, pp. 78-93.

Naumann, S.E. and Bennett, N. (2000), "A case for procedural justice climate: development and test of a multilevel model”, Academy of Management Journal, Vol. 43 No. 5, pp. 881-889.

Ng, T.W.H., Sorensen, K.L. and Eby, L.T. (2006), "Locus of control at work: a meta-analysis", Journal of Organizational Behavior, Vol. 27 No. 1, pp. 1057-1087.

Norman, S.M., Gardner, D.G. and Pierce, J.L. (2015), "Leader roles, organization-based self-esteem, and employee outcomes”, Leadership \& Organization Development Journal, Vol. 36 №. 3, pp. 253-270.

Ohana, M. (2014), "A multilevel study of the relationship between organizational justice and affective commitment”, Personnel Review, Vol. 43 No. 5, pp. 654-671.

Pan, X.F., Qin, Q. and Gao, F. (2014), "Psychological ownership, organization-based self-esteem and positive organizational behaviors", Chinese Management Studies, Vol. 8 No. 1, pp. 127-148.

Pierce, J.L. and Gardner, D.G. (2004), "Self-esteem within the work and organizational context: a review of the organization-based self-esteem literature", Journal of Management, Vol. 30 No. 5, pp. 591-622.

Pierce, J.L., Gardner, D.G., Cummings, L.L. and Dunham, R.B. (1989), "Organization-based self-esteem: construct definition, measurement, and validation", Academy of Management Journal, Vol. 32 No. 3, pp. 622-648.

Pierce, J.L., Gardner, D.G., Dunham, R.B. and Cummings, L.L. (1993), "The moderating effects of organization-based self-esteem on role condition-employee response relationships", Academy of Management Journal, Vol. 36, pp. 271-288.

Popoola, S.O. (2009), "Organizational commitment of records management personnel in Nigerian private universities", Records Management Journal, Vol. 19 No. 3, pp. 204-217.

Porter, L.W., Steers, R.M., Mowday, R.T. and Boulian, P.V. (1974), "Organizational commitment, job satisfaction, and turnover among psychiatric technicians", Journal of Applied Psychology, Vol. 59 No. 5, pp. 603-609.

Preacher, K.J. and Hayes, A.F. (2008), "Asymptotic and resampling strategies for assessing and comparing indirect effects in multiple mediator models", Behavior Research Methods, Vol. 40 No. 3, pp. 879-891.

Purcell, J., Kinnie, N., Swart, J., Rayton, B. and Hutchinson, S. (2008), People Management and Performance, Routledge, Abingdon.

Rotter, J.B. (1966), “Generalized expectancies for internal versus external control of reinforcement", Psychological Monographs: General and Applied, Vol. 80 No. 1, pp. 1-28.

Seligman, M.E.P., Steen, T.A., Park, N. and Peterson, C. (2005), "Positive psychology progress", American Psychologist, Vol. 60 No. 5, pp. 410-421.

Simons, T. and Roberson, Q. (2003), "Why managers should care about fairness: the effects of aggregate justice perceptions on organizational outcomes", Journal of Applied Psychology, Vol. 88 No. 3, pp. 432-443.

Spector, P.E. (1988), "Development of the work locus of control scale", Journal of Occupational Psychology, Vol. 61 No. 4, pp. 335-340.

Suman, S. and Srivastava, A.K. (2012), "Antecedents of organizational commitment across hierarchical levels”, Psychology and Developing Societies, Vol. 24 No. 1, pp. 61-83.

Thibaut, J. and Walker, L. (1975), Procedural Justice: A Psychological Analysis, Erlbaum, Hillsdale, NJ.
Moderating role of individual variables 
PR

46,8

1650

Vandenberghe, C. (2009), “«Organizational commitments »”, in Klein, H.J., Becker, T.E. and Meyer, J.P. (Eds), Commitment in Organizations: Accumulated Wisdom and New Directions, Routledge, New York, NY, pp. 99-135.

Wiesenfeld, B.M., Swann, W.B. Jr, Brockner, J. and Bartel, C. (2007), "Is more fairness always preferred? Self-esteem moderates reactions to procedural justice”, Academy of Management Journal, Vol. 50 No. 5, pp. 1235-1253.

Wright, P.M. and Nishii, L.H. (2006), "Strategic HRM and organizational behavior: Integrating multiple levels of analysis", CAHRS Working Paper No. 06-05, Cornell University, Center for Advanced Human Resource Studies, Ithaca, NY.

Wright, T. and Cropanzano, R. (2004), "The role of psychological well-being in job performance: a fresh look at an age-old quest”, Organizational Dynamics, Vol. 33 No. 4, pp. 338-351.

Yousaf, A., Sanders, K. and Abbas, Q. (2015), "Organizational/occupational commitment and organizational/ occupational turnover intentions: a happy marriage?”, Personnel Review, Vol. 44 No. 4, pp. 470-491.

\title{
Further reading
}

Banking Regulation and Supervision Board, available at: www.bddk.org.tr/WebSitesi/english/ Statistical_Data/Statistical_Data.aspx

The Banks Association of Turkey, available at: www.tbb.org.tr/en/banks-and-banking-sectorinformation/statistical-reports

\begin{abstract}
About the authors
Jale Minibas-Poussard is a Professor Emeritus of Galatasaray University. Presently, she is an Associate Researcher in the Universite Paris-Est, IRG (EA2354), UPEC, UPEM, Créteil, in France. Her current research areas are organizational justice, mobbing, belief in a just world, self-esteem, social representations, consumers' perception and attitudes.

Jeanne Le Roy is an Assistant Professor in the Division of Management and Strategy, European Business School of Paris, in France. Member of IREBS, her current research includes organizational justice, organizational commitment, and organizational deviance (constructive or destructive). Jeanne Le Roy is the corresponding author and can be contacted at: jeanneleroy@ebs-paris.com

Turhan Erkmen is an Associate Professor, and is currently working at Ylldı Technical University, Faculty of Economics and Administrative Sciences, Business Administration Department, Organizational Behavior Chair. His research interests include organizational culture and ethics, psychological capital, organizational commitment and citizenship, organizational image and reputation.
\end{abstract}

For instructions on how to order reprints of this article, please visit our website:

www.emeraldgrouppublishing.com/licensing/reprints.htm

Or contact us for further details: permissions@emeraldinsight.com 